\title{
Quantitative Proteomic Analysis of Cellular Responses to a Designed Amino Acid Feed in a Monoclonal Antibody Producing Chinese Hamster Ovary Cell Line
}

\author{
Fatemeh Torkashvand ${ }^{1}$, Fereidoun Mahboudi ${ }^{1}$, Manouchehr Vossoughi ${ }^{2}$, Elnaz Fatemi ${ }^{1}$, \\ Seyed Masoud Moosavi Basri ${ }^{1}$, Amir Heydari ${ }^{3}$ and Behrouz Vaziri ${ }^{1^{*}}$ \\ ${ }^{1}$ Medical Biotechnology Department, Biotechnology Research Center, Pasteur Institute of Iran, Tehran, Iran; \\ ${ }^{2}$ Department of Chemical and Petroleum Engineering, Biochemical and Bioenvironmental Research \\ Center Sharif University of Technology, Tehran, Iran; ${ }^{3}$ Department of Chemical \\ Engineering, University of Mohaghegh Ardabili, Ardabil, Iran
}

Received 28 January 2018; revised 10 March 2018; accepted 12 March 2018

\begin{abstract}
Background: Chinese hamster ovary $(\mathrm{CHO})$ cell line is considered as the most common cell line in the biopharmaceutical industry because of its capability in performing efficient post-translational modifications and producing the recombinant proteins, which are similar to natural human proteins. The optimization of the upstream process via different feed strategies has a great impact on the target molecule expression and yield. Methods: To determine and understand the molecular events beneath the feed effects on the CHO cell, a labelfree quantitative proteomic analysis was applied. The proteome changes followed by the addition of a designed amino acid feed to the monoclonal antibody producing $\mathrm{CHO}$ cell line culture medium were investigated. Results: The glutathione synthesis, the negative regulation of the programmed cell death, proteasomal catabolic process, and the endosomal transport pathway were up-regulated in the group fed with a designed amino acid feed compared to the control group. Conclusion: Our findings could be helpful to identify new targets for metabolic engineering. DOI: 10.29252/ibj.22.6.385
\end{abstract}

Keywords: $\mathrm{CHO}$ cells, Glutathione, Monoclonal antibodies, Proteomics

Corresponding Author: Behrouz Vazir

Medical Biotechnology Department, Biotechnology Research Center, Pasteur Institute of Iran, Tehran, Iran; Tel.: (+98-21) 64112467;

Fax: (+98-21) 66480780; E-mail: behrouz-vaziri@pasteur.ac.ir

\section{INTRODUCTION}

$\mathrm{C}$ hinese hamster ovary $(\mathrm{CHO})$ cells are desired hosts for the production of biopharmaceuticals. Their ability to perform efficient posttranslational modifications and to produce the recombinant proteins, which are similar to natural human proteins, making them the most common cell line in the biopharmaceutical industry. Moreover, these cells are simply adapted to grow in a serum-free medium $^{[1,2]}$. The use of fully chemically defined serum-free media has simplified the downstream processing and minimized the batch-to-batch variations ${ }^{[3]}$. Over the past two decades, the development of $\mathrm{CHO}$ cells with a considerable production yield has mainly been related to the process engineering strategies so as to optimize the media and feeds formulation, new feeding strategies, and the culture conditions ${ }^{[4,5]}$. Other approaches to achieve a high titer of biopharmaceuticals in $\mathrm{CHO}$ cells are genetic engineering through different expression vector $\operatorname{design}^{[6]}$, cell engineering via the manipulation of the genes associated with the cell cycle $^{[7]}$, cell metabolism $^{[8]}$, apoptosis ${ }^{[9,10]}$, and the protein secretion pathway ${ }^{[11]}$. Until now, the achievement rate of the protein titer enhancement through the genetic and cell 
engineering has been little compared to the bioprocess optimization methods ${ }^{[5]}$.

The full characterization of cellular machinery of the $\mathrm{CHO}$ cells will result in more knowledge regarding the improvement of the manufacturing processes ${ }^{[12]}$. Despite the advances in improving the biopharmaceuticals productivity of the $\mathrm{CHO}$ cells, the complete characterization of their cellular machinery has still to be achieved ${ }^{[13]}$. In order to reach the comprehensive understanding of the $\mathrm{CHO}$ cell physiology and subsequently, the profound knowledge of the biopharmaceuticals production, systems biology approach has been employed ${ }^{[14,15]}$. Furthermore, in order to understand the cellular mechanism of the high productivity in $\mathrm{CHO}$ cells, different systems biology tools like transcriptomics, proteomics, and metabolomics have been applied ${ }^{[16,17]}$. Previous investigations that used the systems biology tools have studied differences between the cell line productivity $^{[18-22]}$ and the changes in culture conditions, including the temperature shift ${ }^{[23]}$, sodium butyrate treatment ${ }^{[24,25]}$, and hyperosmolarity ${ }^{[26]}$, which enhance the productivity. Previous proteomic studies have also provided rational strategies for the modifications needed to increase productivity, develop cell growth, improve media consumption, and provide constant glycosylation patterns ${ }^{[27-38]}$.

It is important to comprehend the molecular rationale of the final production increase by the feed compounds. Such knowledge will help bring about the design of new generation feeds to engineer the new cellular processes ${ }^{[17,39]}$. In this study, by using the label-free quantitative proteomic analysis, protein expression profiles were investigated, followed by the addition of a designed amino acid feed. Through this comparative proteomic study, correlation of the key biological processes influenced by the designed feed, along with the enhancement of the target protein productivity in the $\mathrm{CHO}$ cell line were shown. To the best of our knowledge, this is the first proteomic report that considers the effect of feed formulation on the biological processes during the production of the target monoclonal antibody (mAb) in $\mathrm{CHO}$ cells.

\section{MATERIALS AND METHODS}

\section{Cell line and culture media}

Recombinant $\mathrm{CHO}$ cell producing Bevasizumab, a $\mathrm{mAb}$ against the vascular endothelial growth factor $\mathrm{A}$, was kindly provided by Aryogen Pharmed (Alborz, Iran). The cell line original source was purchased from the Life Technologies (California, USA). The basal culture medium was $\mathrm{CDM} 4 \mathrm{CHO}$ (Hyclone
Laboratories, Utah, USA), which was supplemented with six mM L-glutamine (Lonza, Verviers, Belgium) at the moment of the preparation according to the manufacturer's instruction.

\section{Culture conditions}

The $\mathrm{CHO}$ cells were cultured in a 500-ml shaker flask with an effective volume of $100 \mathrm{ml}$, incubated at $37{ }^{\circ} \mathrm{C}$ with $5 \% \quad \mathrm{CO}_{2}$ and agitated at $80 \mathrm{rpm}$. In the middle of the logarithmic phase, a temperature shift to $32{ }^{\circ} \mathrm{C}$ was performed. Each shaker flask was inoculated with an approximate cell density of $5 \times 10^{5}$ cells/ml

\section{Feeds and their components}

The feeds used in this study were a home-made designed amino acid feed (feed A) and a control feed (feed B). The home-made designed amino acid feed containing $75 \mathrm{mM}$ aspartic acid, $15 \mathrm{mM}$ glutamic acid, $2.5 \mathrm{mM}$ glycine, and $12.5 \mathrm{mM}$ arginine (HiMedia Laboratories, Mumbai, India) was prepared based on the design of experiment methods, reported in our previous study ${ }^{[40]}$. In summary, the critical amino acids for the enhancement of target $\mathrm{mAb}$ production were determined employing the Plackett-Burman design. After finding the critical amino acids, their concentration in the feed was optimized by response surface methodology using a Box-Behncken design. The amino acids were dissolved in the basal medium (CDM4CHO), as control feed, and all the feeds were added, as multiple, discrete additions to the culture on days 3,5 , and 7 .

\section{Proteomic analysis}

Three biological replicate cultures from each group cultured in shaker flasks were examined using the label-free quantitative proteomic analysis. The samples were harvested on day 10. A total of 30 million cells were collected from each replicate of the cell line. The cell suspensions were centrifuged at $180 \times \mathrm{g}$ at $4{ }^{\circ} \mathrm{C}$ for $5 \mathrm{~min}$. The cell pellets were washed three times with isotonic sucrose solution $(250 \mathrm{mM})$. The cells were resuspended in lysis buffer ( $7 \mathrm{M}$ of urea, $2 \mathrm{M}$ of thiourea, $4 \%$ CHAPS $40 \mathrm{mM}$ of Tris, $0.2 \%$ Biolyte $3 / 10$, and $50 \mathrm{mM}$ of dithiothreitol). The whole-cell extracts were kept at room temperature for $60 \mathrm{~min}$, followed by centrifugation at $14,000 \times \mathrm{g}$ at $4{ }^{\circ} \mathrm{C}$ for 15 min. The samples were digested by the filter-aided sample preparation method ${ }^{[41]}$. The digested peptides were suspended in $10 \mu \mathrm{l}$ of $0.1 \%$ formic acid and subjected to nanoLC-MS/MS analysis.

Reverse-phase ultra-high pressure liquid chromategraphy (UPLC) separation of the intracellular protein digests was performed on Easy-nLC1000 (Thermo 
Fisher Scientific, USA) equipped with an in-house made column $(100 \mu \mathrm{m} \times 10 \mathrm{~cm})$ packed with a reversed-phase ReproSil-Pur C18-AQ resin (3 $\mu \mathrm{m}, 120$ $\AA$, Dr. Maisch GmbH, Germany). A linear gradient from 0 to $50 \%$ mobile phase B $(0.1 \%$ formic acid in $80 \%$ acetonitrile) was achieved against the mobile phase A $(0.1 \%$ formic acid in water) over $50 \mathrm{~min}$. LTQ-Orbitrap Elite mass spectrometry (Thermo Fisher Scientific) was used along with UPLC to acquire the mass and fragmentation information of the digested peptides.

RAW files were extracted using the Mascot version 2.3.02 (Matrix Science, London, UK) embedded into Proteome Discoverer 2.0 (Thermo Fisher Scientific). Mass spectrometry data were searched against UniProt, Chinese hamster sequence database (http://www. uniprot.org/). Parameters were set as follows: fully tryptic peptides with $\leq 2$ missed cleavages were permitted; carbamidomethylation and oxidization were fixed and variable modifications, respectively: peptide mass tolerance was $10 \mathrm{ppm}$, and fragment mass tolerance was $20 \mathrm{mmu}$; the charge state of the peptides were set from +2 to +6 . The cut-off of global false discovery rate for peptide and protein identification was set to 0.01 .

Chromatographic peak intensity (peak area) was calculated. Protein species with at least two unique peptides were selected for protein species quantitation, and the relative quantitative protein ratios between the two samples were calculated by comparing the average of $\log 2$-transformed abundance values (three biological replicates). Student's $t$-tests were performed to determine the significance of changes between samples. A fold-change $\geq 1.5$ and $p \leq 0.05$ were used as the thresholds to define differentially accumulated protein species.

\section{Bioinformatic analysis}

Bioinformatic analysis of proteins was conducted according to Liu et al. ${ }^{[42]}$. Functional annotation and category analysis was carried out using an online software, Blast2GO (http://www.geneontology.org). A $p \leq 0.05$ was used as the threshold to determine the significant enrichments of GO pathways.

\section{Western blot analysis}

Western blot analysis was performed as described before in detail ${ }^{[43]}$. Aliquots of the protein samples (35 $\mu \mathrm{g}$ ) were loaded on $12 \%$ SDS-PAGE. Subsequently, they were transferred to a nitrocellulose membrane using the Towbin buffer $(25 \mathrm{mM}$ of Tris, $192 \mathrm{mM}$ of glycine, and $20 \%$ methanol) by a semi-dry Trans-Blot cell (Bio-Rad, USA), and transfer was verified by Ponceau $\mathrm{S}$ staining. The membrane was incubated in a blocking buffer $(2.5 \%$ skim milk, $2.5 \%$ glycerol, and $0.05 \%$ Tween-20 in TBS) at $4{ }^{\circ} \mathrm{C}$ overnight. Furthermore, the membrane was rinsed in TTBS (100 $\mathrm{mM}$ of Tris- $\mathrm{HCl}, 0.9 \% \mathrm{NaCl}$, and $0.05 \%$ Tween-20, $\mathrm{pH} 7.5$ ) for $10 \mathrm{~min}$. It was then incubated for $2 \mathrm{~h}$ with a blocking solution containing primary antibodies: 1:10,000 rabbit monoclonal to glutathione synthetase (GSS), 1:1000 rabbit polyclonal to glucose-6phosphate dehydrogenase (G6PDH), 1:1000 rabbit polyclonal to proteasome subunit beta (PSMB), and 1:1000 rabbit polyclonal to beta-actin (all from Abcam, USA). After washing three times for $5 \mathrm{~min}$ each with TTBS, the membrane was incubated again for $1 \mathrm{~h}$ in 1:500 horseradish peroxidase-conjugated anti-rabbit IgG secondary antibody (RayBiotech, Iran). The immunoreactive bands were then detected by ECL plus kit (GE healthcare, UK) using Kodak Image Station 4000MM Pro.

\section{RESULTS}

The label-free quantitative proteomic analysis was incorporated to find the potential pathways and related gene targets to enhance the $\mathrm{CHO}$ cell productivity via the appropriate feeds. Comparative proteomics was performed on two groups: control and feed A. Three biological replicates were performed for each group, and the whole cell lysates from six shaker flasks were harvested on day 10 and further processed for the label-free analysis. The feeds were added as multiple discrete additions to the cultures on days 3,5 , and 7 . In comparison to the control group, the final mAb titer increased by $70 \%$ in the group fed with feed A (Fig. 1A). Moreover, the viable cell density and viability percentage of the designed amino acid feed group improved (Fig. 1B and 1C).

The label-free protein identification and the differential expression

The whole cell lysates from the biological replicates were harvested on day 10 and prepared for the labelfree quantitative proteomic analysis. Label-free analysis results were provided as supplementary materials. On day 10, 41 proteins in the feed A group were differentially expressed in comparison with the control group. Among these proteins, 30 and 11 proteins were up-regulated and down-regulated, respectively in feed A group in comparison with the control feed group (Table 1).

\section{The up-regulation of important biological processes}

The differentially expressed proteins were identified and clustered by the biological process 

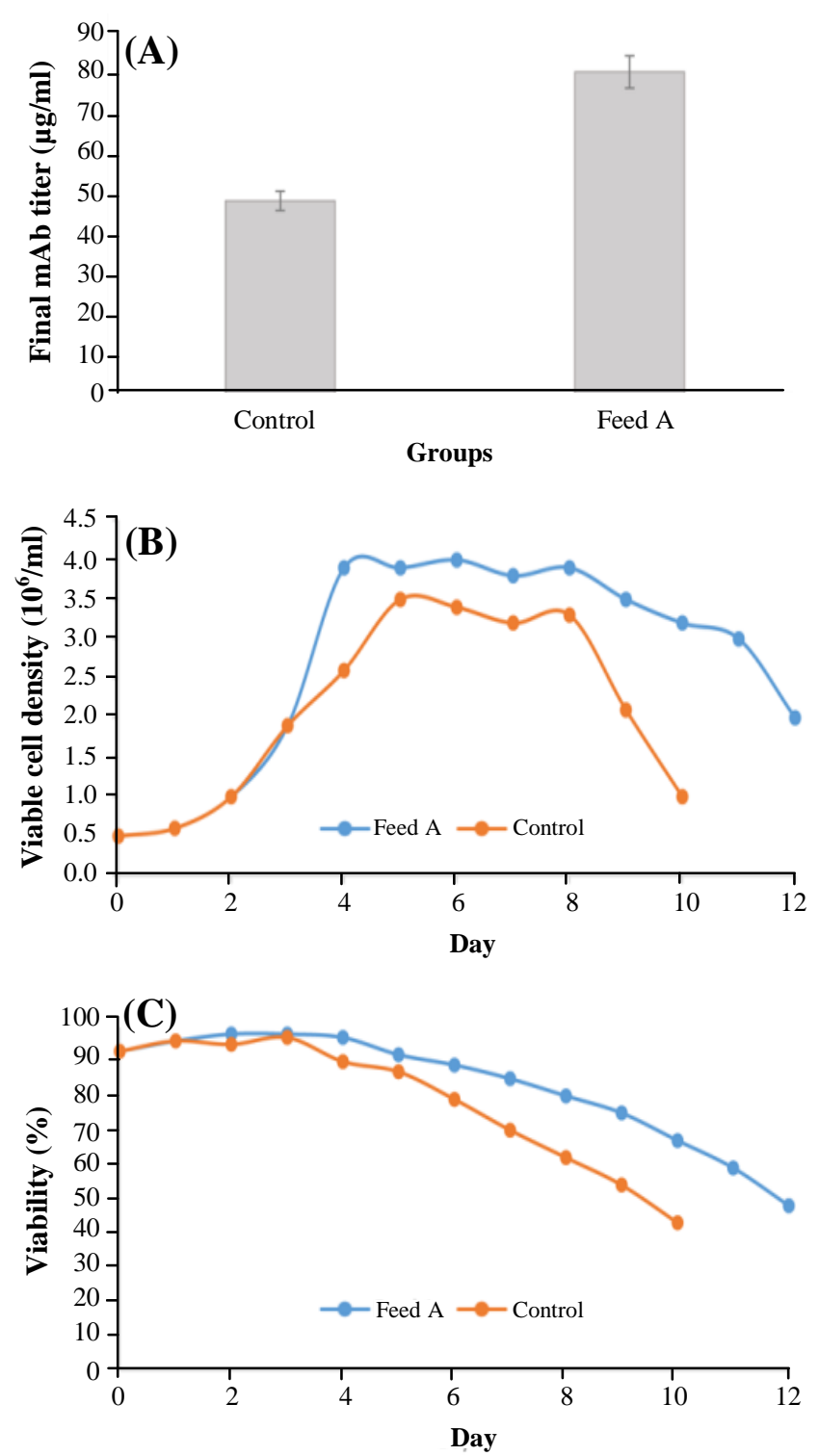

Fig. 1. The final $\mathrm{mAb}$ titer (A), the viable cell density (B), and the viability percentage $(\mathrm{C})$ in feed A group vs. control group.

using Mus musculus homologues and subjected to gene enrichment analysis by the gene ontology consortium. The significant clusters that were upregulated in feed A group in comparison with the control feed group are presented in Table 2. The pentose-phosphate shunt, the glutathione (GSH) metabolic process, the negative regulation of the programmed cell death, the cellular response to the oxidative stress, the regulation of intracellular transport, and the proteasomal protein catabolic process were up-regulated in the group fed with feed $\mathrm{A}$, in comparison with the control group. There was no significant biological process for the down-regulated proteins in feed A.

\section{Western blot analysis result}

Western blot analysis of some of the differentially expressed proteins confirmed all the alterations identified by LC-MS/MS (Fig. 2). The selected proteins for Western blot analysis belonged to different biological processes. G6PDH, GSS, and PSMB were from pentose phosphate shunt, GSH metabolic process, and proteasomal protein catabolic process, respectively.

\section{DISCUSSION}

The up-regulation of GSH pathway was identified in feed A group as compared to the control feed group. GSH is a significant antioxidant and plays several important roles in cells. GSH synthesis occurs in two steps: (1) glutamatecysteine ligase condensates cysteine and glutamate, and (2) a glycine is added by GSS to form $\mathrm{GSH}^{[44]}$. It was found that GSS was upregulated in feed A on day 10 and was confirmed by Western blot analysis (Fig. 2). The up-regulation of this protein in the high-producing cell line has also been reported by Orellana et al. ${ }^{[19]}$.

GSH mediates the correct protein disulfide bond formation by reducing the incorrect protein disulfide bonds via the protein disulfide-isomerase in the endoplasmic reticulum $(\mathrm{ER})^{[45,46]}$. Furthermore, GSH can be oxidized to GSSG in order to detoxify the reactive oxygen species (ROS), which may result in the down-regulation of apoptosis (Fig. 3), and then GSSG can be reduced once more using nicotinamide adenine dinucleotide phosphate (NADPH) to complete the GSH redox cycle ${ }^{[47,48]}$. NADPH can be provided by the pentose phosphate shunt, which was also up-regulated in feed A group in comparison with the control group (Fig. 3). Moreover, G6PD catalyzes the rate limiting step of the pentose phosphate shunt, and the main function of this protein is to provide NADPH ${ }^{[49]}$. G6PD was also up-regulated in feed A on day 10 and was confirmed by Western blot analysis (Fig. 2). The upregulation of $\mathrm{GSH}$ in the high $\mathrm{mAb}$ producing $\mathrm{CHO}$ cells has also been reported in previous studies ${ }^{[19,20]}$. Two main causes of high oxidative stress in the highproducing $\mathrm{CHO}$ cells are: the stress from the protein folding in ER and the stress from the mitochondrial respiration $^{[20]}$. Recent studies have proposed some strategies to mAb-producing $\mathrm{CHO}$ cells for the metabolic engineering of the GSH preservation ${ }^{[50,51]}$.

In the present proteomic analysis, the overexpression of proteins, which were involved in the negative regulation of apoptosis, was found. Furthermore, the batch duration and viability percentage were in line with this event, and the batch duration of feed A group 
Table 1. The list of differentially expressed proteins in feed A group

\begin{tabular}{|c|c|c|c|c|}
\hline No. & Protein name & Protein ID & $\begin{array}{c}\text { Fold } \\
\text { change }\end{array}$ & $\begin{array}{c}\text { Mus musculus } \\
\text { homologous }\end{array}$ \\
\hline 1 & Cystine/glutamate transporter & A0A098KXA0 & 3.2 & Q9WTR6 \\
\hline 2 & Lactoylglutathionelyase & A0A061 & 2.4 & Q9CPU0 \\
\hline 3 & Carboxylic ester hydrolase & A0A061IAA7 & 2.3 & Q64176 \\
\hline 4 & Hydroxymethylglutaryl-CoA synthase, mitochondrial & G3HP76 & 2.3 & P54869 \\
\hline 5 & Glutathione S-transferase & G3IFJ6 & 2.2 & P30115 \\
\hline 6 & Bifunctionalmethylenetetrahydrofolate dehydrogenase/cyclohydrolase & A0A061HZ57 & 2.0 & P18155 \\
\hline 7 & Plasminogen activator inhibitor 1 & G3HA54 & 2.0 & P22777 \\
\hline 8 & Transgelin & G3H7Z2 & 2.0 & Q9WVA4 \\
\hline 9 & Extracellular matrix protein 1 & G3H2W6 & 1.9 & Q61508 \\
\hline 10 & Low-density lipoprotein receptor & P35950 & 1.9 & P35951 \\
\hline 11 & Alpha-2-macroglobulin receptor-associated protein & G3GWB3 & 1.8 & P55302 \\
\hline 12 & Hemeoxygenase 1 & G3IAI6 & 1.8 & P14901 \\
\hline 13 & 4F2 cell-surface antigen heavy chain & G3IHN6 & 1.8 & P108522 \\
\hline 14 & Macrophage migration inhibitory factor & G3HY08 & 1.8 & P34884 \\
\hline 15 & Glutathione S-transferase & G3I5H1 & 1.8 & P24472 \\
\hline 16 & Phosphoserine aminotransferase & G3IKH9 & 1.7 & Q99K85 \\
\hline 17 & Macrophage metalloelastase & G3GUV3 & 1.7 & Q63341 \\
\hline 18 & 3 beta-hydroxysteroid dehydrogenase/Delta 5-->4-isomerase type 2 & G3I6D1 & 1.7 & $\mathrm{P} 24815$ \\
\hline 19 & Calponin & G3I3W0 & 1.7 & Q9DAW9 \\
\hline 20 & von Willebrand factor A domain-containing protein $5 \mathrm{~A}$ & G3IMX9 & 1.7 & Q99KC8 \\
\hline 21 & Glucose-6-phosphate 1-dehydrogenase & O55044 & 1.6 & Q00612 \\
\hline 22 & Guanine nucleotide-binding protein subunit gamma & G3H7D1 & 1.6 & Q80SZ7 \\
\hline 23 & Prolyl 4-hydroxylase subunit alpha-1 & G3HJ24 & 1.6 & Q60715 \\
\hline 24 & CD44 antigen & P20944 & 1.5 & P15379-2 \\
\hline 25 & Bone marrow stromal antigen 2 & A0A061IGY1 & 1.5 & Q8R2Q8 \\
\hline 26 & Galectin & G3H7B3 & 1.5 & $\mathrm{P} 16110$ \\
\hline 27 & Glutathione peroxidase & G3HF60 & 1.5 & O70325 \\
\hline 28 & EH domain-containing protein 1 & G3I6F9 & 1.5 & Q9WVK4 \\
\hline 29 & Glutathione synthetase & G3HAP7 & 1.5 & P51855 \\
\hline 30 & Proteasome subunit beta type & G3H303 & 1.5 & P99026 \\
\hline 31 & Lamin-B receptor & G3GRA0 & -1.5 & Q3U9G9 \\
\hline 32 & UDP-N-acetylhexosaminepyrophosphorylase-like protein 1 & G3IJB9 & -1.5 & Q3TW96 \\
\hline 33 & Lon proteasehomolog, mitochondrial & G3HCJ1 & -1.6 & Q8CGK3 \\
\hline 34 & Translocon-associated protein subunit gamma & G3H223 & -1.6 & Q9DCF9 \\
\hline 35 & Mitochondrial-processing peptidase subunit alpha & G3I6Z3 & -1.6 & Q9DC61 \\
\hline 36 & $\mathrm{NAD}(\mathrm{P})$ transhydrogenase, mitochondrial & G3HMX6 & -1.7 & Q61941 \\
\hline 37 & Periaxin & A0A061I2N6 & -1.7 & unreviewed \\
\hline 38 & Protein unc-84-like B & G3I2J5 & -1.7 & Q8BJS4 \\
\hline 39 & Protein AHNAK2-like protein & A0A061I4K9 & -1.9 & O55103-2 \\
\hline 40 & NADH-cytochrome b5 reductase & G3H3L4 & -2.1 & Q9DB73 \\
\hline 41 & CDGSH iron sulfur domain-containing protein 1 & G3H4L8 & -2.8 & Q91WS0 \\
\hline
\end{tabular}

Table 2. Up-regulated significant biological processes in feed A

\begin{tabular}{clcc}
\hline No. & Biological process & $\boldsymbol{p}$ value & GO ID \\
\hline 1 & Pentose-phosphate shunt & 0.01447 & 0006098 \\
2 & NADPH regeneration & 0.01558 & 0006740 \\
3 & Glutathione metabolic process, & 0.000001697 & 0006749 \\
4 & Negative regulation of programmed cell death (apoptotic signaling pathway) & 0.00001436 & 2001234 \\
5 & Carboxylic acid biosynthetic process & 0.01058 & 0046394 \\
6 & Cellular response to oxidative stress & 0.02598 & 0034599 \\
7 & Regulation of vesicle-mediated transport & 0.001639 & 0060627 \\
& Regulation of intracellular transport & 0.02796 & 0032386 \\
8 & Proteasomal protein catabolic process & 0.02336 & 0010498 \\
\hline
\end{tabular}

GO, gene ontology 


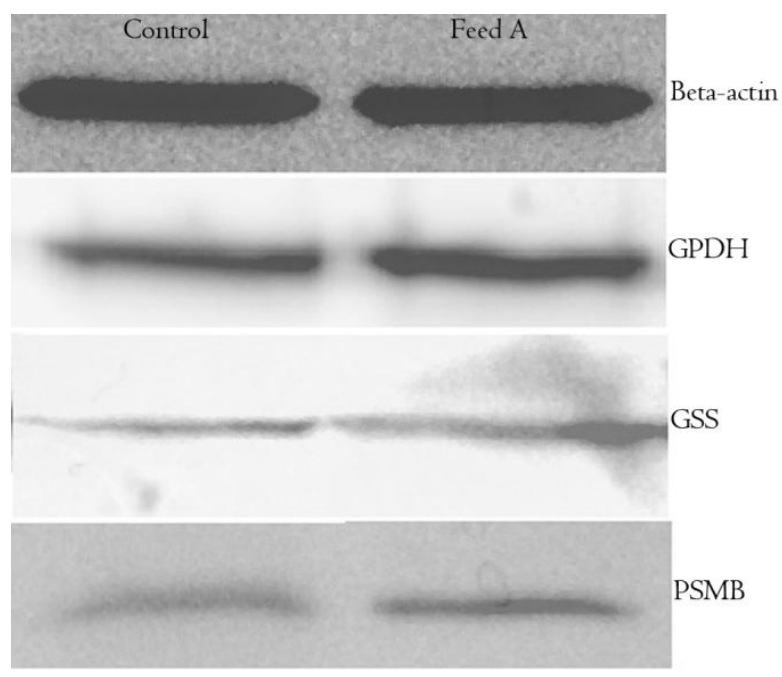

Fig. 2. Western blot images of beta-actin, G6PDH, GSS, and PSMB of control group and designed amino acid feed group (feed A). Beta-actin was used as a control protein. was more than that of the control feed group (Fig. 1B and 1C). The cell apoptosis may occur in a fed-batch culture because of the hyperosmolarity, the by-product accumulation, and the production of $\operatorname{ROS}^{[52,53]}$. The use of a suitably designed feed can delay the apoptosis and extend the culture duration, which leads to an increase in the $\mathrm{mAb}$ productivity ${ }^{[54]}$. The negative regulation of the programmed cell death has been attributed to the role of GSH in the reduction of $\operatorname{ROS}^{[47]}$, which also seems to be true in this study (Fig. 3). Based on the results obtained from this study, it seems that increase in productivity is due to increased integral viable cell density and somewhat to increased specific productivity.

In the recombinant protein production process, the protein translation and secretion are considered as bottlenecks ${ }^{[55,56]}$. There are different transport vesicles in cells, and the up-regulation of the proteins that constitute these vesicles has already been reported, as a

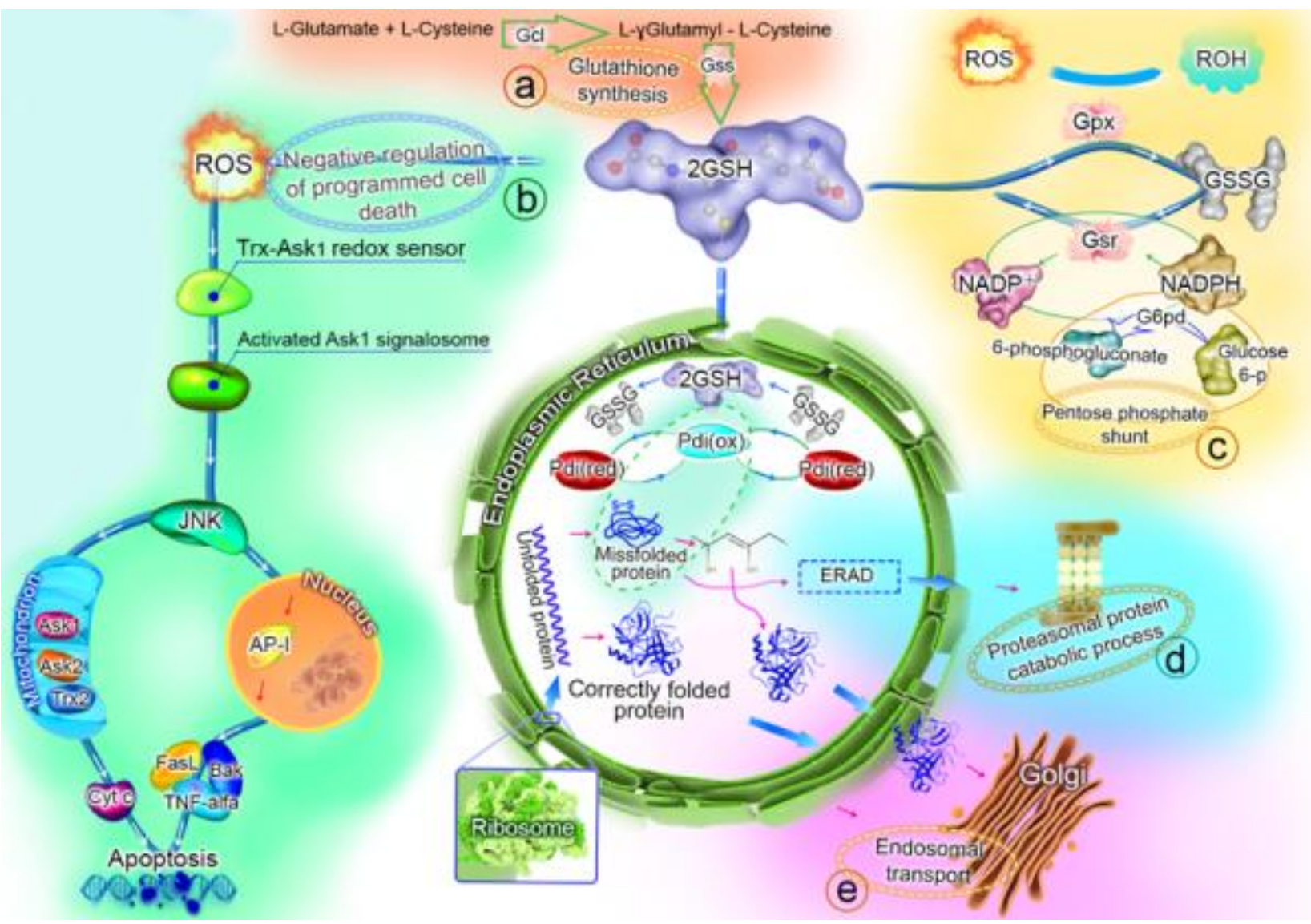

Fig. 3. The suggested functions for the up-regulated biological processes in feed A group on day 10. The GSH synthesis (a), the negative regulation of programmed cell death (b), the pentose phosphate shunt (c), the proteasomal protein catabolic process (d), and the endosomal transport (e) were up-regulated processes in feed A group compared with the control feed group. The details and the roles of these processes in the final mAb titer enhancement have been explained in the text. GSH, glutathione (oxidized form); GSSG, glutathione (reduced form); Gcl, glutamatecysteine ligase; GSS, glutathione synthetase; Gpx, glutathione peroxidase; Gsr, glutathione reductase; G6pd, glucose-6-phosphate 1-dehydrogenase; Pdi, protein disulfide-isomerase; ERAD, endoplasmic reticulum-associated protein degradation; ROS, reactive oxygen species. 
result of recombinant protein overexpression ${ }^{[57]}$. The up-regulation of intracellular protein transport in the high mAb-producing $\mathrm{CHO}$ cells has also been reported by Orellana et $a l .{ }^{[19]}$. In line with these reports, the present research demonstrates that the proteins involved in the intracellular transport and the vesiclemediated transport such as the transitional ER ATPase, filamin A, and AP-2 complex subunit mu are upregulated after the addition of appropriate feed. AP-2 is involved in the endocytosis and the transport from the trans-Golgi network to the lysosomes ${ }^{[58]}$. Another report has also showed the up-regulation of AP-2 in the high $\mathrm{mAb}$ producing cells ${ }^{[19]}$.

If the protein production in cells increases, the misfolded proteins rate will also increase ${ }^{[59]}$. In order to prevent the accumulation of misfolded proteins, their retrotranslocation from ER to cytosol, when they undergo the ubiquitination, will occur, and these misfolded proteins will be the substrates for proteasome ${ }^{[60]}$. In addition, the up-regulation of the proteasomal catabolic process was seen in feed A, and the up-regulation of proteasome subunit beta was confirmed by Western blot analysis. This study shows that the feed composition will affect mAb production by changing the different pathways regulation, which are likely correlated to culture productivity.

\section{ACKNOWLEDGMENTS}

This work has financially been supported by the Science and Technology Development division of Aryogen Pharmed, Iran. The authors would like to acknowledge the Creative Proteomics, the proteomics division of the Creative Dynamics Inc, USA.

CONFLICT OF INTEREST. None declared.

\section{REFERENCES}

1. Kim JY, Kim YG, Lee GM. CHO cells in biotechnology for production of recombinant proteins: current state and further potential. Applied microbiology and biotechnology 2012; 93(3): 917-930.

2. Wurm FM. Production of recombinant protein therapeutics in cultivated mammalian cells. Nature biotechnology 2004; 22(11): 1393-1398.

3. Rodrigues ME, Costa AR, Henriques M, Cunnah P, Melton DW, Azeredo J, Oliveira R. Advances and drawbacks of the adaptation to serum-free culture of CHO-K1 cells for monoclonal antibody production. Applied biochemistry and biotechnology 2013; 169(4): 1279-1291.

4. Hacker DL, De Jesus M, Wurm FM. 25 years of recombinant proteins from reactor-grown cells - where do we go from here? Biotechnology advances 2009; 27(6): 1023-1027.

5. Wuest DM, Harcum SW, Lee KH. Genomics in mammalian cell culture bioprocessing. Biotechnology advances 2012; 30(3): 629-638.

6. Lim Y, Wong NS, Lee YY, Ku Sc, Wong DC, Yap MG. Engineering mammalian cells in bioprocessing - current achievements and future perspectives. Biotechnology and applied biochemistry 2010; 55(4): 175-89.

7. Fussenegger M, Schlatter S, Dätwyler D, Mazur X, Bailey JE. Controlled proliferation by multigene metabolic engineering enhances the productivity of Chinese hamster ovary cells. Nature biotechnology 1998; 16(5): 468-472.

8. Fogolín MB, Wagner R, Etcheverrigaray M, Kratie R. Impact of temperature reduction and expression of yeast pyruvate carboxylase on hGM-CSF-producing $\mathrm{CHO}$ cells. Journal of biotechnology 2004; 109(1-2):179-191.

9. Chiang GG, Sisk WP. Bcl-x(L) mediates increased production of humanized monoclonal antibodies in Chinese hamster ovary cells. Biotechnology and bioengineering 2005; 91(7): 779-792.

10. Krampe B, Al-Rubeai M. Cell death in mammalian cell culture: molecular mechanisms and cell line engineering strategies. Cytotechnology 2010; 62(3): 175-188.

11. Mohan C, Park SH, Chung JY, Lee GM. Effect of doxycycline-regulated protein disulfide isomerase expression on the specific productivity of recombinant CHO cells: thrombopoietin and antibody. Biotechnology and bioengineering 2007; 98(3): 611-615.

12. Meleady P, Hoffrogge R, Henry M, Rupp O, Bort JH, Clarke C, Brinkrolf K, Kelly S, Müller B, Doolan P, Hackl M, Beckmann TF, Noll T, Grillari J, Barron N, Pühler A, Clynes M, Borth N. Utilization and evaluation of CHO-specific sequence databases for mass spectrometry based proteomics. Biotechnology and bioengineering 2012; 109(6): 1386-1394.

13. Baycin-Hizal D, Tabb DL, Chaerkady R,Chen L, Lewis NE, Nagarajan H, Sarkaria V, Kumar A, Wolozny D,Colao J, Jacobson E, Tian Y, O'Meally RN, Krag SS, Cole RN, Palsson BO, Zhang H, Betenbaugh M. Proteomic analysis of Chinese hamster ovary cells. Journal of protome research 2012; 11(11): 5265-5276.

14. Xiao S, Shiloach J, Betenbaugh MJ. Engineering cells to improve protein expression. Current opinion in structural biology 2014; 26:32-8.

15. Lewis AM, Abu-Absi NR, Borys MC, Li ZJ. The use of 'Omics technology to rationally improve industrial mammalian cell line performance. Biotechnology and bioengineering 2016; 113(1): 26-38.

16. Dietmair S, Nielsen LK, Timmins NE. Mammalian cells as biopharmaceutical production hosts in the age of omics. Biotechnology journal 2012; 7(1): 75-89.

17. Farrell A, McLoughlin N, Milne JJ, Marison IW, Bones J. Application of multi-omics techniques for bioprocess design and optimization in chinese hamster ovary cells. Journal of proteome research 2014; 13(7): 3144-3159.

18. Kang S, Ren D, Xiao G, Daris K, Buck L, Enyenihi AA, Zubarev R, Bondarenko PV, Deshpande R. Cell line 
profiling to improve monoclonal antibody production. Biotechnology and bioengineering 2014; 111(4): 748760.

19. Orellana CA, Marcellin E, Schulz BL, Nouwens AS, Gray PP, Nielsen LK. High-antibody-producing Chinese hamster ovary cells up-regulate intracellular protein transport and glutathione synthesis. Journal of proteome research 2015; 14(2): 609-618.

20. Chong WP, Thng SH, Hiu AP, Lee DY, Chan EC, Ho YS. LC-MS-based metabolic characterization of high monoclonal antibody-producing Chinese hamster ovary cells. Biotechnology and bioengineering 2012; 109(12): 3103-3111.

21. Nissom PM, Sanny A, Kok YJ, Hiang YT, Chuah SH, Shing TK, Lee YY, Wong KT, Hu WS, Sim MY, Philp R. Transcriptome and proteome profiling to understanding the biology of high productivity $\mathrm{CHO}$ cells. Molecular biotechnology 2006; 34(2): 125-140.

22. Gao Y, Ray S, Dai S, Ivanov AR, Abu-Absi NR, Lewis AM, Huang Z, Xing Z, Borys MC, Li ZJ, Karger BL. Combined metabolomics and proteomics reveals hypoxia as a cause of lower productivity on scale-up to a 5000-liter $\mathrm{CHO}$ bioprocess. Biotechnology journal 2016; 11(9): 1190-1200.

23. Yee JC, Gerdtzen ZP, Hu WS. Comparative transcriptome analysis to unveil genes affecting recombinant protein productivity in mammalian cells. Biotechnology and bioengineering 2009; 102(1): 246263.

24. Yee JC, de Leon Gatti M, Philp RJ, Yap M, Hu WS. Genomic and proteomic exploration of $\mathrm{CHO}$ and hybridoma cells under sodium butyrate treatment. Biotechnology and bioengineering 2008; 99(5): 11861204.

25. Kantardjieff A, Jacob NM, Yee JC, Epstein E, Kok YJ, Philp R, Betenbaugh M, Hu WS. Transcriptome and proteome analysis of Chinese hamster ovary cells under low temperature and butyrate treatment. Journal of biotechnology 2010; 145(2): 143-159.

26. Lee MS, Kim KW, Kim YH, Lee GM. Proteome analysis of antibody-expressing $\mathrm{CHO}$ cells in response to hyperosmotic pressure. Biotechnology and progress 2003; 19(6): 1734-1741.

27. Van Dyk DD, Misztal DR, Wilkins MR, Mackintosh JA, Poljak A, Varnai JC, Teber E, Walsh BJ, Gray PP. Identification of cellular changes associated with increased production of human growth hormone in a recombinant Chinese hamster ovary cell line. Proteomics 2003; 3(2): 147-156.

28. Carlage T, Hincapie M, Zang L, Lyubarskaya $\mathrm{Y}$, Madden H, Mhatre R, Hancock WS. Proteomic profiling of a high-producing Chinese hamster ovary cell culture. Analytical chemistry 2009; 81(17): 7357-7362.

29. Carlage T, Kshirsagar R, Zang L, Janakiraman V, Hincapie M, Lyubarskaya Y, Weiskopf A, Hancock WS. Analysis of dynamic changes in the proteome of a Bcl-XL overexpressing Chinese hamster ovary cell culture during exponential and stationary phases. Biotechnology progress 2012; 28(3): 814-823.

30. Kuystermans D, Dunn MJ, Al-Rubeai M. A proteomic study of cMyc improvement of $\mathrm{CHO}$ culture. $B M C$ biotechnology 2010; 10: 25.

31. Lee JS, Park HJ, Kim YH, Lee GM. Protein reference mapping of dihydrofolate reductase-deficient $\mathrm{CHO}$ DG44 cell lines using 2-dimensional electrophoresis. Proteomics 2010;10(12): 2292-2302.

32. Baik JY, Ha TK, Kim YH, Lee GM. Proteomic understanding of intracellular responses of recombinant chinese hamster ovary cells adapted to grow in serum-free suspension culture. Biotechnology progress 2011; 27: 1680-1688.

33. Meleady P, Doolan P, Henry M, , Keenan J, O'Sullivan F, Clarke C, Gammell P, Melville MW, Leonard M, Clynes M. Sustained productivity in recombinant Chinese hamster ovary ( $\mathrm{CHO}$ ) cell lines: proteome analysis of the molecular basis for a process-related phenotype. BMC biotechnology 2011; 11: 78.

34. Wei YYC, Naderi S, Meshram M, Budman H, Scharer JM, Ingalls BP, McConkey BJ. Proteomics analysis of chinese hamster ovary cells undergoing apoptosis during prolonged cultivation. Cytotechnology 2011; 63(6): 663677.

35. Stolfa G, Smonskey MT, Boniface R, Hachmann AB, Gulde P, Joshi AD, Pierce AP, Jacobia SJ, Campbell A. CHO-Omics Review: The impact of current and emerging technologies on Chinese hamster ovary based bioproduction. Biotechnology journal 2018; 13(3): e1700227.

36. Dorai H, Liu S, Yao X, Wang Y, Tekindemir U, Lewis MJ, Wu SL, Hancock W. Proteomic analysis of bioreactor cultures of an antibody expressing CHO-GS cell line that promotes high productivity. Journal of proteomics and bioinformatics 2013; 6: 98-108.

37. Liu Z, Dai S, Bones J, Ray S, Cha S, Karger BL, Li JJ, Wilson L, Hinckle G, Rossomando A. A quantitative proteomic analysis of cellular responses to high glucose media in Chinese hamster ovary cells. Biotechnology progress 2015; 31(4): 1026-1038.

38. Xu N, Ma C, Ou J, Sun WW, Zhou L, Hu H, Liu XM. Comparative proteomic analysis of three Chinese hamster ovary (CHO) host cells. Biochemical engineering journal 2017; 124: 122-129.

39. Neilson KA, Ali NA, Muralidharan S, Mirzaei M, Mariani M, Assadourian G, Lee A, van Sluyter SC, Haynes PA. Less label, more free: approaches in labelfree quantitative mass spectrometry. Proteomics 2011; 11(4): 535-553.

40. Torkashvand F, Vaziri B, Maleknia S, Heydari A, Vossoughi M, Davami F, Mahboudi F. Designed amino acid feed in improvement of production and quality targets of a therapeutic monoclonal antibody. PLoS one 2015; 10(10): e0140597.

41. Wisniewski JR, Zougman A, Nagaraj N, Mann M. Universal sample preparation method for proteome analysis. Nature methods 2009; 6(5): 359-362.

42. Liu J, Pang C, Wei H, Song M, Meng Y, Ma J, Fan S, Yu S. iTRAQ-facilitated proteomic profiling of anthers from a photosensitive male sterile mutant and wild-type cotton (Gossypium hirsutum L.). Journal of proteomics 2015; 126: 68-81. 
43. Vaziri B, Torkashvand F, Eslami N, Fayaz A. Comparative proteomics analysis of mice lymphocytes in early stages of infection by different strains of rabies virus. Indian journal of virology 2012; 23(3): 311-316.

44. Meister A. Glutathione, ascorbate, and cellular protection. Cancer research 1994; 54(7 Suppl): 1969s1975s.

45. Kojer K, Riemer J. Balancing oxidative protein folding: the influences of reducing pathways on disulfide bond formation. Biochimica et biophysica acta 2014; 1844(8): 1383-1390.

46. Lappi AK, Ruddock LW. Reexamination of the role of interplay between glutathione and protein disulfide isomerase. Journal of molecular biology 2011; 409(2): 238-249.

47. Circu ML, Aw TY. Glutathione and modulation of cell apoptosis. Biochimica et biophysica acta 2012; 182(10): 1767-1777.

48. McIlwain CC, Townsend DM, Tew KD. Glutathione Stransferase polymorphisms: cancer incidence and therapy. Oncogene 2006; 25(11): 1639-1648.

49. Tuttle S, Stamato T, Perez ML, Biaglow J. Glucose-6phosphate dehydrogenase and the oxidative pentose phosphate cycle protect cells against apoptosis induced by low doses of ionizing radiation. Radiation research 2000; 153(6): 781-787.

50. Selvarasu S, Ho YS, Chong WP, Wong NS, Yusufi FN, Lee YY, Yap MG, Lee DY. Combined in silico modeling and metabolomics analysis to characterize fed-batch CHO cell culture. Biotechnology and bioengineering 2012; 109(6): 1415-1429.

51. Chong WP, Yusufi FN, Lee DY, Reddy SG, Wong NS, Heng CK, Yap MG, Ho YS. Metabolomics-based identification of apoptosis-inducing metabolites in recombinant fed-batch $\mathrm{CHO}$ culture media. Journal of biotechnology 2011; 151(2): 218-224.

52. Butler M. Animal cell cultures: recent achievements and perspectives in the production of biopharmaceuticals. Applied microbiology and biotechnology 2005; 68(3): 283-291.

53. Han YK, Kim YG, Kim JY, Lee GM. Hyperosmotic stress induces autophagy and apoptosis in recombinant Chinese hamster ovary cell culture. Biotechnology and bioengineering 2010; 105(6): 1187-1192.

54. Han YK, Ha TK, Lee SJ, Lee JS, Lee GM. Autophagy and apoptosis of recombinant Chinese hamster ovary cells during fed-batch culture: effect of nutrient supplementation. Biotechnology and bioengineering 2011; 108(9): 2182-2192.

55. Schröder M. Engineering eukaryotic protein factories. Biotechnology letters 2008; 30(2): 187-196.

56. Dinnis DM, James DC. Engineering mammalian cell factories for improved recombinant monoclonal antibody production: lessons from nature? Biotechnology and bioengineering 2005; 91(2): 180189.

57. Kuge O, Dascher C, Orci L, Rowe T, Amherdt M, Plutner H, Ravazzola M, Tanigawa G, Rothman JE, Balch WE. Sar1 promotes vesicle budding from the endoplasmic reticulum but not Golgi compartments. The journal of cell biology 1994; 125(1): 51-65.

58. Motley AM, Berg N, Taylor MJ, Sahlender DA, Hirst J, Owen DJ, Robinson MS. Functional analysis of AP-2 alpha and mu2 subunits. Molecular biology of the cell 2006; 17(12): 5298-5308.

59. Walter P, Ron D. The unfolded protein response: from stress pathway to homeostatic regulation. Science 2011; 334(6059): 1081-1086.

60. Lemus L, Goder V. Regulation of Endoplasmic Reticulum-Associated Protein Degradation (ERAD) by Ubiquitin. Cells 2014; 3(3): 824-847. 